\title{
Evaluation of the impact of residual anhydramnios following preterm premature rupture of membranes on respiratory distress syndrome
}

\author{
Erdem Şahin (D), Yusuf Madendağ \\ Department of Obstetrics and Gynecology, Medical School, Erciyes University, Kayseri, Turkey
}

\begin{abstract}
Objective: The aim of the present study was to evaluate the impact of residual anhydramnios following preterm premature rupture of membranes (PPROM) on respiratory distress syndrome (RDS) after the pregnancy was expectantly managed.

Methods: This study was retrospectively conducted at Erciyes University Medical School, Turkey. It assessed women with singleton pregnancies admitted to the hospital between 2010 and 2020 for expectant management of PPROM between 24th and 28th gestational weeks. The patients were divided into three groups as follows: (1) anhydramnios, (2) oligohydramnios, (3) normal amniotic fluid volume (AFV). Main outcome measure was as follows: The first evaluation was $\mathrm{AFV}$ at admission and the primary outcome was a neonatal RDS. Adjusted odds ratios (aOR) and $95 \%$ confidence interval (CI) for RDS were calculated for each AFV-at-presentation adjusting for gestational age (GA) at PPROM, GA at delivery, latency period, birth-weight percentile, cesarean birth, and chorioamnionitis.

Results: Of the 440 women with PPROM, 261 fulfilled the inclusion criteria. There were 125 (47.8\%) with normal AFV, 71 (27.3\%) with oligohydramnios, and 65 (24.9\%) with anhydramnios at admission. The maternal demographic characteristics were similar among the groups. Birth weight was significantly different among the groups. RDS was highest in the anhydramnios group (64.6\%). Decreased $\mathrm{AFV}$ was not associated with RDS in either oligohydramnios or anhydramnios at presentation. A GA at PPROM, latency period >30 days, and cesarean delivery were co-factors in the outcome.

Conclusion: Our results indicated that oligohydramnios and anhydramnios were not associated with RDS risk, but GA at PPROM and delivery, latency period, and cesarean delivery were independently associated with the RDS risk.
\end{abstract}

Keywords: Preterm premature rupture of membranes, amniotic fluid volume, residual anhydramnios, respiratory distress syndrome.

\section{Özet: Preterm erken membran rüptürü sonrası rezidüel anhidramniyozun respiratuvar distres sendromu üzerindeki etkisinin değerlendirilmesi}

Amaç: Çalışmamızın amacı, gebeliğin yakın izlem şekilde yönetilmesinden sonra preterm erken membran rüptürü sonrası rezidüel anhidramniyozun respiratuvar distres sendromu (RDS) üzerindeki etkisini değerlendirmekti.

Yöntem: Bu çalışma, Erciyes Üniversitesi Tıp Fakültesinde retrospektif olarak gerçekleştirildi. Çalışmada, gebeliğin 24 ile 28 . haftaları arasında yakın izlem PEMR yönetimi için 2010 ile 2020 yılları arasında hastaneye başvuran tekil gebelik olguları değerlendirildi. Hastalar şu üç gruba ayrıldı: (1) anhidramniyoz, (2) oligohidramniyoz, (3) normal amniyotik sıvı hacmi (ASH). Ana sonuç ölçümleri İlk değerlendirme başvurudaki ASH iken birincil sonuç neonatal RDS idi. RDS için düzeltilmiş olasılık oranları (aOR) ve \%95 güven aralığı (GA); PEMR'de gestasyonel yaş (GY), doğumda GY, gecikme dönemi, doğum ağırlığı persantili, sezaryen doğum ve koryoamniyonit bakımından düzeltilen her bir başvurudaki ASH için hesapland.

Bulgular: PEMR'li 440 kadının 261'i çalışmaya dahil olma kriterlerini karşıladı. Başvuruda normal ASH'li 125 (\% 47.8) olgu, oligohidramniyozlu 71 (\%27.3) olgu ve anhidramniyozlu 65 (\%24.9) olgu vardı. Maternal demografik özellikler, gruplar arasında benzerdi. Doğum ağırlığı, gruplar arasında anlamlı şekilde farklıydı. RDS, anhidramniyoz grubunda en yüksek seviyedeydi (\%64.6). Azalmış ASH, başvuruda oligohidramniyoz veya anhidramniyoz grubunda RDS ile ilişkili değildi. PEMR'de GY, 30 günden büyük gecikme dönemi ve sezaryen doğum, sonuçta ortak faktörlerdi.

Sonuç: Sonuçlarımız, oligohidramniyoz ve anhidramniyozun RDS riskiyle ilişkili olmadığını, fakat PEMR ve doğumda GY'nin, gecikme döneminin ve sezaryen doğumun bağımsız olarak RDS riskiyle ilişkili olduğunu göstermektedir.

Anahtar sözcükler: Preterm erken membran rüptürü, amniyotik s1vı hacmi, rezidüel anhidramniyoz, respiratuvar distres sendromu.

Correspondence: Yusuf Madendağ, MD. Department of Obstetrics and Gynecology, Medical School, Erciyes University, Kayseri, Turkey. e-mail: yusufmadendag@gmail.com / Received: November 13, 2020; Accepted: January 17, 2021

How to cite this article: Şahin E, Madendağ Y. Evaluation of the impact of residual anhydramnios following preterm premature rupture of membranes on respiratory distress syndrome. Perinatal Journal 2021;29(1):13-19. doi:10.2399/prn.21.0291003 


\section{Introduction}

Preterm premature rupture of membranes (PPROM), defined as fetal membrane rupture without signs of labor $<37$ weeks gestation, seriously complicates $3-4 \%$ of all pregnancies and is a major risk for perinatal morbidity and mortality. Fetal death from PPROM may occur mainly due to reasons such as preterm birth, anhydramnios, umbilical cord compression, prolapsed umbilical cord, perinatal infection and abruptio placentae..$^{[1-4]}$ Amniotic fluid is required for normal fetal development and growth. ${ }^{[5]}$ Fetal pulmonary development depends on sufficient amniotic fluid; hence severe oligohydramnios during pregnancy can cause pulmonary hypoplasia. ${ }^{[6,7]}$ Pulmonary hypoplasia is mainly associated with severe oligohydramnios $<22$ weeks gestation. ${ }^{[6,8,9]}$

Respiratory distress syndrome (RDS) is a widespread and life-threatening disease of neonates and a major cause of morbidity and mortality in premature infants. ${ }^{[10]}$ Surfactant is a liquid made by the lungs of an unborn baby beginning at $\sim 26$ gestational weeks that keeps the airways open and allows a baby to breathe in air after delivery. When there is a surfactant deficiency, RDS develops and can lead to abnormal respiratory function as the baby proceeds to neonatal life; ${ }^{[10]}$ hence, it is critical that this condition be determined early in the pregnancy. ${ }^{[11]}$ The aim of the present study was to evaluate the impact of residual oligohydramnios and anhydramnios after PPROM on RDS even when the pregnancy was expectantly managed.

\section{Methods}

This study was retrospectively conducted at Erciyes University Medical School, Turkey, and approved by the ethics committee of the university (2019/51); it was conducted in accordance with the Declaration of Helsinki. The present study assessed women with a singleton pregnancy admitted to Erciyes University Medicine School with PPROM at $24+0$ to $28+6$ weeks of gestation between January 1, 2010 and June 1, 2020, and who had undergone expectant management. We wanted to evaluate impact of long-term latency period (>20 days) on RDS, hence; pregnant women with PPROM at 24th to 29th weeks of gestation were included to the study. The exclusion criteria were as follows: (1) necessity of immediate delivery, (2) multifetal gestations, (3) cases with missing data, (4) major fetal anomaly, (5) chronic hypertension, (6) gestational hypertension, (7) preeclampsia, (8) intrauterine growth restriction, (9) collagen vascular disease, (10) gestational diabetes mellitus, (11) types 1 and 2 diabetes, or (12) chronic systemic disease. The flow chart of the study population is illustrated in Fig. 1.

We identified the patients diagnosed with PPROM from the hospital's database, subsequently, we examined the demographic characteristics, medical and obstetric history, age of gestation (GA) in diagnosis of PPROM, duration of the latency period, and complications related to pregnancy treatment (e.g. chorioamnionitis, maternal sepsis, or placental abruption). Newborn characteristics were also evaluated for RDS, birth weight, GA at delivery, and Apgar assessment.

Amniotic fluid volume (AFV) was the primary clinical measure of a membrane rupture on presentation to the hospital and the ultrasound examination was conducted that included an estimation of fetal weight and a biophysical profile. During the first clinical examination of those admitted to the clinic with membrane rupture, a four-quadrant technique was used to ultrasonographically measure AFV. An anhydramnios AFI is defined as $\leq 2 \mathrm{~cm}$, oligohydramnios AFI as $2-5 \mathrm{~cm}$, and normal AFI as $8-24 \mathrm{~cm} \cdot{ }^{[12]}$ The PPROM patients studied were divided into the following three groups for assessing residual AFV: (1) anhydramnios, (2) oligohydramnios, and (3) normal AFV.

The primary outcome to be assessed in the present study was neonatal RDS, which was identified by some pediatricians who was blinded to the Doppler evaluations. Other factors in an RDS diagnosis were the existence of diffuse, fine, granular densities and decreased pulmonary volume with a higher oxygen necessity. ${ }^{[13]}$

A trained obstetrician diagnosed PPROM after the patient was admitted to the hospital. The presence of amniotic fluid either passing through the cervix or pooling in the uterine fornix indicated PPROM. The nitrazine paper test and a ferning pattern seen on the dried vaginal secretions indicated the presence of amniotic fluid and a ruptured membrane. The date of the beginning of the patient's last menstrual cycle was used to determine her gestational week; if that date was not known, the gestational age was calculated using ultrasonographic measurements taken during the first trimester. The protocol comprised monitoring daily vital signs and uterine tenderness, administered a nonstress test twice/day, assessing the biophysical profile twice/week, and administering $1 \mathrm{~g}$ azithromycin orally 


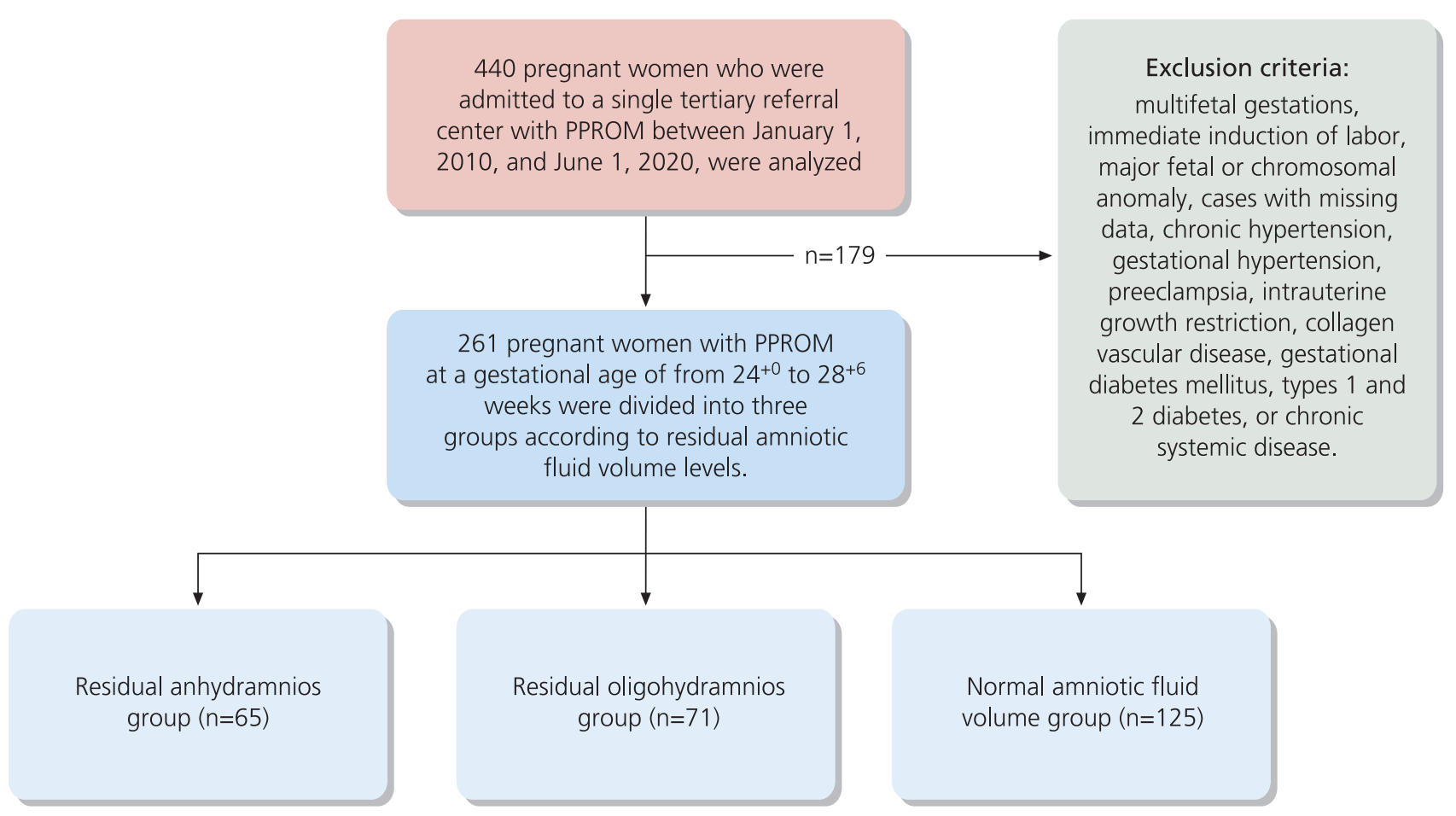

Fig. 1. Flow chart for the study population.

at admission. While hospitalized, $2 \mathrm{~g}$ ampicillin was administered intravenously every $6 \mathrm{~h}$ for 2 day, followed by $500 \mathrm{mg}$ amoxicillin orally three times/day or $875 \mathrm{mg}$ orally two times/day for an additional 5 day. ${ }^{[14]}$ Vaginal examinations were refrained during the pregnant woman was asymptomatic. If necessary, a sterile speculum inspection was opted to digital examination. PPROM women with a cervical cerclage were assessed for whether to remove the cerclage. ${ }^{[15]}$ After the diagnosis of PPROM, two doses of $12 \mathrm{mg}$ betamethasone were administered intramuscularly every 24 hours. ${ }^{[16]}$ Magnesium sulfate was applied for impact of fetal neuro-protection in women who gave birth at before 32 weeks of gestation. ${ }^{[17]}$ Women with PPROM who were at risk of intrauterine infection or placental abruption or who had non-reassuring fetal testing or a high risk of cord prolapse were counseled on the preference of an expeditious delivery. If both the mother and the fetus were stable, the pregnancy continued to be managed and delivery was preferred at 34th weeks. A diagnosis of chorioamnionitis was made if the woman had a temperature of $\geq 38.0^{\circ} \mathrm{C}$ without cause not related to the pregnancy, and at least two of the following conditions were observed: leukocytosis, new-onset foul-smelling vaginal discharge, uterine tenderness, maternal or fetal tachycardia. ${ }^{[18]}$ In the absence of congenital anomalies, fetal growth restriction (FGR) was diagnosed according to Delphi consensus criteria. ${ }^{[19]}$ Maternal sepsis was identified when there were symptoms belong to end-organ dysfunction such as hypotension, oliguria, high creatinine, diffuse intravascular coagulation, or respiratory failure in the presence of maternal infection such as tachycardia, positive blood cultures and fever. Placental abruption was diagnosed based mainly on evidence of new onset vaginal bleeding, recurring painful contractions, and bloody amniotic fluid or blood clots in the placenta during birth.

Statistical analyses were conducted using SPSS version 20.0 (IBM Inc., Armonk, NY, USA). The KruskalWallis $\mathrm{H}$ test was used to test the normality of the data. The Levene test was used to evaluate the assumption of variance homogeneity; values are expressed as the mean \pm standard deviation, median (25th-75th percentile), or $\mathrm{n}(\%)$. One-way analysis of variance was used to compare multiple groups after evaluating for normal distribution. Multivariate logistic regression analysis was used to 
assess the relationship between the $\mathrm{AFV}$ at presentation and the primary outcome (the normal AFV group was used as reference), while adjusting for possible confounding factors including chorioamnionitis, GA at PPROM, GA at delivery, latency period, birth weight, and cesarean birth.

\section{Results}

Of the 440 women applied with PPROM in the period of study, 261 fulfilled the inclusion criteria (see Fig. 1; flow chart). There were 125 (47.8\%) patient with normal AFV, 71 (27.3\%) with oligohydramnios, and 65 (24.9\%) with anhydramnios at admission. Demographic features of the all study patients according to AFV at admission are showed in Table 1. Maternal age, nulliparity, body mass index, ethnicity, and previous cesarean delivery were similar among the groups $(\mathrm{p}=0.330, \mathrm{p}=0.680$, $\mathrm{p}=0.320, \mathrm{p}=0.650$, and $\mathrm{p}=0.580$, respectively).

Maternal and newborn outcomes in all study groups are showed in Table 2. Birth at a GA earlier than that in the normal AFV and oligohydramnios groups $(\mathrm{p}<0.001)$ was primarily a result of the differences in the time of the latency period; this period was lower in anhydramnios group than in the others $(\mathrm{p}<0.001)$. There were no significant differences among the groups in terms of cesarean delivery, chorioamnionitis, maternal sepsis, placental abruption, or cord prolapse ( $\mathrm{p}=0.920, \mathrm{p}=0.480, \mathrm{p}=0.240$, $\mathrm{p}=0.870$, and $\mathrm{p}=0.470$, respectively). The rate of $\mathrm{RDS}$ was $64.6 \%$ in the anhydramnios group, $39.4 \%$ in the oligohydramnios group and $26.4 \%$ in the normal-AFV group. The rate of RDS was the greatest in the anhydramnios group ( $<<0.001)$ (Table 2). Birth weight was $1488 \pm 208 \mathrm{~g}$ in anhydramnios group, $1716 \pm 183 \mathrm{~g}$ in oligohydramnios group, and $2002 \pm 159 \mathrm{~g}$ in normal-AFV group, a significant difference among the groups $(\mathrm{p}<0.001)$. There were no significant differences among the groups with regard to birth weight percentile, umbil- ical cord $\mathrm{pH}<7.20$, and 5-minute Apgar score $<7$ $(\mathrm{p}=0.740, \mathrm{p}=0.220$, and $\mathrm{p}=0.360$, respectively).

When the normal-AFV group was used as the reference, a multivariate logistic regression analysis was used to assess the relationship between the $\mathrm{AFV}$ at admission and the primary outcome; the data were adjusted for possible confounding factors, such as GA at PPROM, GA at delivery, latency period $>30 \mathrm{~d}$, birth-weight percentile, cesarean delivery, and chorioamnionitis. After adjusting for the variables, we observed that a decreased AFV was not associated with RDS for both oligohydramnios (adjusted odds ratio [AOR], 4.42; 95\% confidence interval [CI], 0.21-07.30) and anhydramnios (AOR, 7.83; 95\% CI, 0.54-77.45) at presentation (Table 3). Other factors that were independently related to the primary outcome were GA at PPROM (AOR, 0.38; 95\% CI, 0.17-0.86), GA at delivery (AOR, 0.14; 95\% CI, 0.04-0.54), latency period $>30 \mathrm{~d}$ (AOR, 0.18; 95\% CI, 0.05-0.54), and cesarean birth (AOR, 2.66; 95\% CI, 1.25-5.68).

\section{Discussion}

Respiratory distress syndrome continues to be a common and life-threatening disease in neonates, particularly in preterm neonates. The aim of the present study was to evaluate the impact of residual oligohydramnios and anhydramnios after PPROM on RDS when the pregnancy was expectantly managed. The results of our assessments were that (1) approximately one-half of the women with early PPROM presented with oligohydramnios, with $24.9 \%$ of them presenting with residual anhydramnios; (2) oligohydramnios and anhydramnios at presentation were not associated with the risk of RDS after adjusting for the variables using multivariate logistic regression analysis; and (3) GA at PPROM, GA at delivery, latency period, and cesarean delivery were independently associated with RDS risk.

Table 1. Comparison of maternal physical characteristics among groups.

\begin{tabular}{lcccc} 
Characteristic & $\begin{array}{c}\text { Anhydramnios } \\
(\mathbf{n}=\mathbf{6 5})\end{array}$ & $\begin{array}{c}\text { Oligohydramnios } \\
\mathbf{( n = 7 1 )}\end{array}$ & $\begin{array}{c}\text { Normal amniotic } \\
\text { fluid volume }(\mathbf{n}=\mathbf{1 2 5})\end{array}$ & $\mathbf{p}$-value* \\
Maternal age (years) & $33.4 \pm 5.1$ & $31.6 \pm 5.9$ & $31.6 \pm 5.7$ & 0.330 \\
\hline Nulliparity & $20(30.7)$ & $22(30.9)$ & $41(32.8)$ & 0.680 \\
\hline Body mass index $\left(\mathrm{kg} / \mathrm{m}^{2}\right)$ & $29.5 \pm 1.1$ & $29.0 \pm 1.3$ & $29.3 \pm 1.5$ & 0.320 \\
\hline Ethnicity (Caucasian) & $62(95.3)$ & $68(95.7)$ & $121(96.8)$ & 0.650 \\
\hline Previous cesarean history & $23(34.3)$ & $25(35.2)$ & $40(32)$ & 0.580 \\
\hline
\end{tabular}

The values were presented the mean \pm SD or $n(\%)$. *All comparisons were made by ANOVA test. 
Table 2. Comparison of perinatal outcomes and respiratory distress syndrome rates among groups.

\begin{tabular}{|c|c|c|c|c|c|}
\hline \multicolumn{2}{|c|}{ Outcomes } & $\begin{array}{l}\text { Anhydramnios } \\
\qquad(\mathrm{n}=65)\end{array}$ & $\begin{array}{l}\text { Oligohydramnios } \\
\qquad(n=71)\end{array}$ & $\begin{array}{c}\text { Normal amniotic } \\
\text { fluid volume }(n=125)\end{array}$ & p-value* \\
\hline \multirow{8}{*}{ 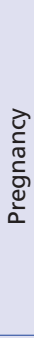 } & Gestational age at PPROM (week) & $26.9 \pm 1.0$ & $27.0 \pm 0.8$ & $27.0 \pm 0.8$ & 0.626 \\
\hline & Gestational age at delivery (week) & $29.9 \pm 1.8^{A}$ & $31.4 \pm 1.9 \mathrm{~B}$ & $32.6 \pm 1.4 \mathrm{C}$ & $<0.001$ \\
\hline & Latency period (day) & $18.5 \pm 4.8 \mathrm{D}$ & $26.2 \pm 7.2^{E}$ & $33.2 \pm 6.2^{F}$ & $<0.001$ \\
\hline & Cesarean delivery & $35(53)$ & $39(55)$ & $71(57)$ & 0.920 \\
\hline & Chorioamnionitis & $11(17)$ & $15(21.1)$ & $18(14.4)$ & 0.480 \\
\hline & Maternal sepsis & $2(3.1)$ & $1(1.4)$ & $1(0.8)$ & 0.240 \\
\hline & Placental abruption & $3(4.6)$ & $3(4.2)$ & $4(3.2)$ & 0.870 \\
\hline & Cord prolapsed & $3(4.6)$ & $2(2.8)$ & $2(1.6)$ & 0.470 \\
\hline \multirow{5}{*}{$\begin{array}{l}\bar{\pi} \\
\stackrel{\pi}{\pi} \\
\tilde{0} \\
\stackrel{d}{z}\end{array}$} & Birth weight (g) & $1488 \pm 208 \mathrm{G}$ & $1716 \pm 183^{H}$ & $2002 \pm 159$ & $<0.001$ \\
\hline & Birth weight percentile & $56 \pm 14.4$ & $58 \pm 17.1$ & $61 \pm 18.6$ & 0.740 \\
\hline & Umbilical cord $\mathrm{pH}<7.20$ & $4(6.2)$ & $2(2.8)$ & $2(1.6)$ & 0.220 \\
\hline & 5-minute Apgar score $<7$ & $5(7.7)$ & $3(4.2)$ & $4(3.2)$ & 0.360 \\
\hline & Respiratory distress syndrome & $42(64.6)^{\jmath}$ & $28(39.4)^{\mathrm{K}}$ & $33(26.4)^{\mathrm{L}}$ & $<0.001$ \\
\hline
\end{tabular}

The values are presented the mean \pm SD or $n(\%)$. ${ }^{*} A l l$ comparisons were made by ANOVA test. PPROM: preterm premature rupture of membranes. $A$ vs $B$ - significant, B vs C - significant, A vs C - significant; D vs E - significant, E vs F - significant, D vs F - significant; $G$ vs $\mathrm{H}$ - significant, $\mathrm{H}_{\text {vs }}$ I - significant, $\mathrm{G}$ vs I - significant; J vs $\mathrm{K}$-significant, $K_{\text {VS }} L$ - not significant, J VS L - significant.

The results of studies on the association between oligohydramnios and poor newborn outcomes in PPROM women are contradictory due to the differences in the inclusion criteria used and the targeted primary results. Some trials did not concentrate about newborn respiratory morbidity as a primary outcome; therefore, the description of respiratory morbidity is not as clear as in our trial. ${ }^{[1,20-23]}$ In addition, the results of most of the studies were not classified considering to the oligohydramnios severity at admission. ${ }^{[1,720-24]}$ Two recent studies aimed to clarify the relationship between residual AFV and respiratory morbidity between 20th and 29th gesta- tional weeks. In their well-designed, large, retrospective study using singleton pregnancies for expectant PPROM management at 20+0 to $28+6$ weeks gestation, Weiner et al. ${ }^{[2]}$ declared that oligohydramnios and severe oligohydramnios at admission are independently related to severe respiratory morbidity, which they described as one of the following: (1) the demand for respiratory assistance and surfactant in the condition of mechanical ventilation applying an endo-tracheal tube for $\geq 3$ days; (2) bronchopulmonary dysplasia described as oxygen demand at 36 weeks gestation or when transferred to a level-II facility. Mousavi et al..$^{[2]}$ have found no statistically significant

Table 3. Logistic regression analysis of associations between delivery characteristics and respiratory distress syndrome in pregnancies complicated by preterm premature rupture of the membrane.

\begin{tabular}{|c|c|c|c|c|}
\hline Respiratory distress syndrome & $\begin{array}{l}\text { Odds ratio } \\
(95 \% \mathrm{Cl})\end{array}$ & p-value & $\begin{array}{l}\text { Adjusted odds } \\
\text { ratio }(95 \% \mathrm{Cl})\end{array}$ & $\begin{array}{c}\text { Adjusted } \\
\text { p-value }\end{array}$ \\
\hline Normal AFV at presentation & Reference & & Reference & \\
\hline Gestational age at PPROM & $0.61(0.41-0.90)$ & 0.18 & $0.38(0.17-0.86)$ & 0.019 \\
\hline Gestational age at delivery & $0.13(0.05-0.30)$ & $<0.001$ & $0.14(0.04-0.54)$ & 0.004 \\
\hline Latency period & $0.06(0.02-0.16)$ & $<0.001$ & $0.18(0.05-0.54)$ & 0.002 \\
\hline Cesarean delivery & $2.22(1.18-4.45)$ & 0.010 & $2.66(1.25-5.68)$ & 0.011 \\
\hline Chorioamnionitis & $2.84(1.45-5.48)$ & 0.002 & $0.28(0.07-1.06)$ & 0.060 \\
\hline Birth weight percentile & $0.76(0.34-1.67)$ & 0.522 & $2.05(0.57-7.40)$ & 0.272 \\
\hline Oligohydramnios at presentation & $1.32(0.30-5.73)$ & 0.720 & $4.42(0.21-7.30)$ & 0.324 \\
\hline Anhydramnios at presentation & $25.48(9.65-67.30)$ & $<0.001$ & $7.83(0.54-77.45)$ & 0.993 \\
\hline
\end{tabular}

AFV: amniotic fluid volume; Cl: confidence interval; PPROM: preterm premature rupture of membrane. 
differences among gestational age at presentation, latency period, gestational age at birth, and RDS rates in PPROM pregnancies at a GA of 26th-29th weeks.

In the present study, after conducting a multivariate logistic regression analysis to evaluate the relationship between the AFV at admission and the primary outcome and while adjusting for important possible confounding factors such as GA at PPROM, GA at delivery, latency period, birth weight percentile, cesarean delivery, and chorioamnionitis, we observed that neither oligohydramnios nor anhydramnios at admission with PPROM was related to RDS risk. In addition, we found that, consistent with the data in the current literature, anhydramnios at presentation is associated with a decreased latency period, GA at delivery, and low birth weight. ${ }^{[1,26-28]}$ Our results can be explained by the data having been adjusted for potential important confounding variables. It is well documented in the literature that consistent with our results, prematurity, low birth weight, and cesarean delivery are major RDS risk factors. ${ }^{[29,30]}$ We know that the primary cause of RDS is a deficiency in pulmonary surfactant, which is developmentally regulated in the preterm infant. In that infant, a decrease in both the quantity and quality of surfactant contributes to decreased surfactant activity, which results in RDS. Inadequate surfactant activity in the developing lungs results in high surface tension, which leads to lung instability at end expiration, low lung volume, and decreased compliance. Surfactant deficiency also leads to lung inflammation and respiratory epithelial injury, possibly causing pulmonary edema and increased airway resistance.

The retrospective nature of our study had some limitations. We recognized that $\mathrm{AFV}$ is dynamic and changes consistently; however, the groups we assessed were described by AFV at admission, without considering the AFV changes pending the latency period. Still, we suggest that AFV is more beneficial for clinical management in admission, because the longitudinal AFV levels are unknown during evaluation. The principal power of the present research were the relatively wide cohort, having the study patients in a single center and managing them considering to a uniformed protocol, adjusting the findings for possible confounding factors, and having a relatively homogeneous cohort that was limited to events of PPROM between 24th and 28th gestational weeks.

\section{Conclusion}

Our results indicated that neither oligohydramnios nor anhydramnios during admission was related to the RDS risk, but that GA at PPROM, GA at delivery, latency period, and cesarean delivery are independently associated with that risk. This knowledge can be taken into account while advising to a pregnant woman with early PPROM about newborn outcome and management choices.

Funding: This work did not receive any specific grant from funding agencies in the public, commercial, or not-for-profit sectors.

Compliance with Ethical Standards: The authors stated that the standards regarding research and publication ethics, the Personal Data Protection Law and the copyright regulations applicable to intellectual and artistic works are complied with and there is no conflict of interest.

\section{References}

1. Ekin A, Gezer C, Taner CE, Özeren M. Perinatal outcomes in pregnancies with oligohydramnios after preterm premature rupture of membranes. J Matern Fetal Neonatal Med 2015;28:1918-22. [PubMed] [CrossRef]

2. Storness-Bliss C, Metcalfe A, Simrose R, Wilson RD, Cooper SL. Correlation of residual amniotic fluid and perinatal outcomes in periviable preterm premature rupture of membranes. J Obstet Gynaecol Can 2012;34:154-8. [PubMed] [CrossRef]

3. Hasegawa J, Ikeda T, Sekizawa A, Ishiwata I, Kinoshita K; Japan Association of Obstetricians and Gynecologists, Tokyo, Japan. Obstetric risk factors for umbilical cord prolapse: a nationwide population-based study in Japan. Arch GynecolObstet 2016;294:467-72. [PubMed] [CrossRef]

4. Lewis DF, Robichaux AG, Jaekle RK, Salas A, Canzoneri BJ, Horton K, et al. Expectant management of preterm premature rupture of membranes and nonvertex presentation: what are the risks? Am J Obstet Gynecol 2007;196:566.e1-5. [PubMed] [CrossRef]

5. Sahin E, Madendag Y, Tayyar AT, Sahin ME, Madendag IC, Acmaz G. Perinatal outcomes in uncomplicated late preterm pregnancies with borderline oligohydramnios. J Matern Fetal Neonatal Med. 2018;31:3085-8. [PubMed] [CrossRef]

6. Wu CS, Chen CM, Chou HC. Pulmonary hypoplasia induced by oligohydramnios: findings from animal models and a population-based study. Pediatr Neonatol 2017;58:37. [PubMed] [CrossRef]

7. Winn HN, Chen M, Amon E, Leet TL, Shumway JB, Mostello D. Neonatal pulmonary hypoplasia and perinatal mortality in patients with midtrimester rupture of amniotic membranes - a critical analysis. Am J Obstet Gynecol 2000; 182:1638-44. [PubMed] [CrossRef]

8. Williams O, Michel B, Hutchings G, Debauche C, Hubinont C. Two-year neonatal outcome following PPROM prior to 25 weeks with a prolonged period of oligohydramnios. Early Hum Dev 2012;88:657-61. [PubMed] [CrossRef]

9. Kotecha S. Lung growth: implications for the newborn infant. Arch Dis Child Fetal Neonatal Ed 2000;82:F69-74. [PubMed] [CrossRef] 
10. Saker F, Martin R. Pathophysiology and clinical manifestations of respiratory distress syndrome in the newborn. Garcia-Prats JA, editor. Waltham (MA): Up-To-Date [database on the internet]; 2013. Available from: http://www.uptodate.com

11. Kamath BD, MacGuire ER, McClure EM, Goldenberg RL, Jobe AH. Neonatal mortality from respiratory distress syndrome: lessons for low-resource countries. Pediatrics 2011; 127:1139-46. [PubMed] [CrossRef]

12. Madendag Y, Madendag IC, Sahin E, Aydin E, Sahin ME, Acmaz G. How well do the popular ultrasonic techniques estimate amniotic fluid volume and diagnose oligohydramnios, in fact? Ultrasound Q 2019;35:35-8. [PubMed] [CrossRef]

13. Büke B, Destegül E, Akkaya H, Şimşek D, Kazandi M. Prediction of neonatal respiratory distress syndrome via pulmonary artery Doppler examination. J Matern Fetal Neonatal Med 2019;32:1640-5. [PubMed] [CrossRef]

14. American College of Obstetricians and Gynecologists' Committee on Practice Bulletins-Obstetrics. Prelabor rupture of membranes: ACOG Practice Bulletin, Number 217. Obstet Gynecol 2020;135:e80-97. [PubMed] [CrossRef]

15. Galyean A, Garite TJ, Maurel K, Abril D, Adair CD, Browne P, et al.; Obstetrics Perinatal Collaborative Research Network. Removal versus retention of cerclage in preterm premature rupture of membranes: a randomized controlled trial. Am J Obstet Gynecol 2014;211:399.e1-7. [PubMed] [CrossRef]

16. American College of Obstetricians and Gynecologists' Committee on Obstetric Pediatrics, Society for Maternal-Fetal Medicine. Committee Opinion No.677: antenatal corticosteroid therapy for fetal maturation. Obstet Gynecol 2016;128: e187-94. [PubMed] [CrossRef]

17. Magee L, Sawchuck D, Synnes A, von Dadelszen P; Magnesium Sulphate For Fetal Neuroprotection Consensus Committee; Maternal Fetal Medicine Committee. SOGC Clinical Practice Guideline. Magnesium sulphate for fetal neuroprotection. J Obstet Gynaecol Can 2011;33:516-29. [PubMed] [CrossRef]

18. Tita ATN, Andrews WW. Diagnosis and management of clinical chorioamnionitis. Clin Perinatol 2010;37:339-4. [PubMed] [CrossRef]

19. Gordijn SJ, Beune IM, Thilaganathan B, Papageorghiou A, Baschat AA, Baker PN, et al. Consensus definition of fetal growth restriction: a Delphi procedure. Ultrasound Obstet Gynecol 2016;48:333-9. [PubMed] [CrossRef]

20. Kurdoglu M, Kolusari A, Adali E, Yildizhan R, Kurdoglu Z, Kucukaydin Z, et al. Does residual amniotic fluid after preterm premature rupture of membranes have an effect on perinatal outcomes? 12 years experience of a tertiary care center. Arch Gynecol Obstet 2010;281:601-7. [PubMed] [CrossRef]

21. Piazze J, Anceschi MM, Cerekja A, Brunelli R, Meloni P, Marzano S, et al. Validity of amniotic fluid index in preterm rupture of membranes. J Perinat Med 2007;35:394-8. [PubMed] [CrossRef]

22. Kacerovsky M, Musilova I, Andrys C, Drahosova M, Hornychova H, Rezac A, et al. Oligohydramnios in women with preterm prelabor rupture of membranes and adverse pregnancy and neonatal outcomes. PLoS One 2014;9:e105882. [PubMed] [CrossRef]

23. Wagner P, Sonek J, Mayr S, Abele H,Goelz R, Hoopmann $M$, et al. Outcome of pregnancies with spontaneous PPROM before 24+0 weeks' gestation. Eur J Obstet Gynecol Reprod Biol 2016;203:121-6. [PubMed] [CrossRef]

24. Mousavi AS, Hashemi N, Kashanian M, Sheikhansari N, Bordbar A, Parashi S. Comparison between maternal and neonatal outcome of PPROM in the cases of amniotic fluid index (AFI) of more and less than $5 \mathrm{~cm}$. J Obstet Gynaecol 2018;38:611-5. [PubMed] [CrossRef]

25. Weiner E, Barrett J, Zaltz A, Ram M, Aviram A, Kibel M, et al. Amniotic fluid volume at presentation with early preterm prelabor rupture of membranes and association with severe neonatal respiratory morbidity. Ultrasound Obstet Gynecol 2019;54:767-73. [PubMed] [CrossRef]

26. Hadi HA, Hodson CA, Strickland D. Premature rupture of the membranes between 20 and 25 weeks' gestation: role of amniotic fluid volume in perinatal outcome. Am J Obstet Gynecol 1994;170:1139-44. [PubMed] [CrossRef]

27. Ekin A, Gezer C, Taner CE, Ozeren M, Uyar I, Gulhan I. Risk factors and perinatal outcomes associated with latency in preterm premature rupture of membranes between 24 and 34 weeks of gestation. Arch Gynecol Obstet 2014;290:449-55. [PubMed] [CrossRef]

28. Park JS, Yoon BH, Romero R, Moon JB, Oh SY, Kim JC, et al. The relationship between oligohydramnios and the onset of preterm labor in preterm premature rupture of membranes. Am J Obstet Gynecol 2001;184:459-62. [PubMed] [CrossRef]

29. Condò V, Cipriani S, Colnaghi M, Bellù R, Zanini R, Bulfoni $\mathrm{C}$, et al. Neonatal respiratory distress syndrome: are risk factors the same in preterm and term infants? J Matern Fetal Neonat Med 2017;30:1267-72. [PubMed] [CrossRef]

30. Li Y, Zhang C, Zhang D. Cesarean section and the risk of neonatal respiratory distress syndrome: a meta-analysis. Arc Gynecol Obstet 2019;300:503-17. [PubMed] [CrossRef]

Publisher's Note: The content of this publication does not necessarily reflect the views or policies of the publisher, nor does any mention of trade names, commercial products, or organizations imply endorsement by the publisher. Scientific and legal responsibilities of published manuscript belong to their author(s). The publisher remains neutral with regard to jurisdictional claims in published maps and institutional affiliations. 